\title{
Co-constructing Colonial Dichotomies in Former Female Colonizers' Narratives of the Belgian Congo
}

\section{Dorien Van De Mieroop \& Mathias Pagnaer}

Focusing on interviews with female former colonials in the Belgian Congo, we analyze the way these interviewees co-construct and negotiate their identities against the backdrop of, and in interaction with, master narratives of colonization in interaction with the interviewer, who is also a former colonial. We focus mainly on stories on family life or in the realm of the household since the colonial home is typically a locus of encounters between the white female colonizers and the black colonized household staff. The findings demonstrate a polarization between blacks and whites in line with colonial ideological views in which the indigenous people are infantilized, thus legitimizing colonization as an endeavor of civilization. As such, these interview narratives seem frozen in time, even though they were told more than four decades after the Congolese independence. We argue that this is not only due to the interactional aspect, in which the two interlocutors set up a local ingroup of white former colonizers, but that it is also a reflection of the current Belgian society in which a broad and thoroughly critical debate about colonial history is fairly absent since it is not based on voices from both sides of the former colonial equilibrium.

[ethnicity, identity, master narrative, natural hierarchies, infantilization, colonization, the Belgian Congo, discourse analysis] 


\section{Introduction}

The view of colonialism as situated on a binary axis of power with the colonizers at the top end and the colonized at the bottom end, has long been debated and has been deemed too simplistic for a reality that was characterized by a great complexity (see e.g. Comaroff 1997: 165; McClintock 1995: 10-11). Of course, the colonizers were typically in a dominant position and this was constructed as "natural," and thus "legitimate" based on a number of different hierarchies - "religious, philosophical, evolutionary, and so on" (Errington 2008: 5). Especially important is the latter, since Darwinism was used to support the evolutionary scale of human types, typically giving the "tribal" peoples a lowly status (Comaroff and Comaroff 2009: 29) as opposed to the racial superiority of white males at the top of the hierarchy. This led to the portrayal of non-white men as childlike, who were "afflicted by an absence, a lack of the qualities that characterized the adult white male ideal of European civilization" (Comaroff and Comaroff 1991: 117). Given the subordinate status of children in the family, this trope "became invaluable in its capacity to give state and imperial intervention the alibi of nature" (McClintock 1995: 45) and legitimize practices such as corporal punishments (Hanks 2010: 64). Darwinian visions also permeated in views on languages, in which “ 'stronger', more 'progressive' languages 'spread' by displacing their less efficient, 'weaker' counterparts" (Errington 2008: 146) and in which African languages were defined as "idioms (parlers, dialects)," rather than as languages, which contained features that were considered “degenerate, vulgar and generally deficient” (Fabian 1986: 82). Furthermore, linguistic diversity and multilingualism supported the thesis of primitivity of the African communities, since this resonated "with Biblical narratives of (monolingual) Eden, and the theology of dispersal from (multilingual) Babel” (Errington 2001: 27). Again, constructing this linguistic situation as problematic enabled Europeans to legitimize regulation from above (Fabian 1986: 81) and the imposition of a European language or a "vehicular language" such as Swahili in 
the Belgian Congo (Errington 2008: 124) further underlined the difference between the rulers and the ruled. As Fabian describes, Europeans in the Belgian Congo learnt Swahili through language manuals which were "not just grammars for command, but embodiments of discipline" (Fabian 1986: 109-110), but they also presented Swahili as "forbiddingly difficult or as ridiculously easy," which discouraged any form of normal communication between Europeans and Africans, thus protecting "professional routines and ideological stereotypes" from "the subversive effects of close human interaction" (Fabian 1986: 136).

However, as mentioned in the beginning, "colonial regimes were neither monolithic nor omnipotent" (Cooper and Stoler 1989: 609). Even though "racial distinction was an organizing principle and a powerful rhetorical theme" (Cooper and Stoler 1989: 611) in the colonies, questions concerning white male supremacy arose because of varying factors such as for example the organizational complexity or cultural variation within African societies (see e.g. Comaroff and Comaroff 1991: 10), the class differences among the colonizers, the issue of interracial sexual contact and the resulting mixed blood progeny (see e.g. Stoler 1997) and the position of women within this cultural hierarchy (see e.g. McClintock 1995). All these issues related to race, gender and class, should not be considered as having an influence in an isolated way, but rather, "they come into existence in and through relation to each other - if in contradictory and conflictual ways" (McClintock 1995: 5). It is precisely the complexity between two of these issues, namely race and gender, which we aim to focus on in this article, and, since as McClintock argues, "the colonial home is a context zone of acute ambivalence" (McClintock 1995: 271), this is an ideal locus for investigating how these issues are discursively constructed and negotiated while colonizers and colonized interact with one another, thus potentially showing the discrepancy between prescription and practice in the colonies (Stoler 2001: 832). 
In particular, we focus on narratives concerning domestic life of a number of Belgian women who lived in the Belgian Congo, the former Belgian African colony and the present day Democratic Republic of Congo, during the fifties. In this period, an increasing number of Belgians moved to the Belgian Congo, usually not to settle permanently, but rather to live there temporarily for occupational and economic reasons. The Belgian colonials thus became part of a young and professionally active community, with around $80 \%$ of the population under 45 (Hermans 2010). However, this professional activity was limited to the male part of the colonial community, since the women typically took care of the children and the household (Verlinden 2002: 36) and coordinated the efforts of the house staff (Stienissen 2009), thus rendering their position in the colonial home crucial. Since direct access to discursive negotiations of issues of race and gender during colonial times is of course impossible, we focus on a number of interviews with these colonial women. We selected a number of narratives mainly about the household and family life and look in particular at the way the interviewees construct their identities vis-à-vis the "other," i.c. the colonized people, since, as McClintock observed, the construction of "the degenerate other" had a crucial influence on the definition of "the normal self" (McClintock 1995: 46), and, in a wider, societal perspective, "Europe was made by its imperial projects" as much as the colonized countries were shaped by the European colonial projects (Stoler and Cooper 1997).

So by studying the ways in which the aforementioned issues come into play in their stories, we relate these personal narratives to the master narratives of white supremacy and natural hierarchies of human types - in which, of course, women typically occupy an ambivalent position (cf McClintock 1995). Such master narratives, or dominant discourses, can be considered as the backdrop against which narrators construct their stories, either by complying with or alternatively countering these socially shared discourses (Bamberg 2006: 145; De Fina, et al. 2006: 7). As such, they either stress respectively the canonicity or the 
exceptionality of the events described in their narratives (Bruner 1991), which of course also has implications regarding the identities that are constructed through these stories. And so, even though it has been observed that "people rely on [such] models to make sense of themselves and others" (Wortham, et al. 2011: 57), this does not at all mean that every individual at that time aligned with these dominant discourses, nor that people, who look back at their "colonial" life after many years, still orient to these specific dominant discourses in the same way as they used to. This is especially because of the drastic political changes (Congo's independence), urging people to question the premises of colonial systems as they are criticized globally and to investigate the actual "otherness" of colonized "others," but also because the interviewees have had so many occasions to reflect upon the events and edit the different versions of their own identities and their life stories (cf Linde 1993: 105). Narrators typically adjust their stories and orient them to their own "subjective definition" (Van Dijk 2009: 248) of the changing global context in which they occur (see e.g. Van De Mieroop, et al. 2007), thus potentially resulting in a politically correct account of the social irrelevance of racial or gender difference - as it is the current opinion in modern day Western societies. This tension between past and present is an important theme that we explore in these narratives, since, as McIntosh observed in her study of the narratives of white Kenyans, "the conflict between 'comforting schemata' and their 'alternatives' is no minor matter" (McIntosh 2009: 73), rather, it has important implications regarding the legitimacy of the roles the interviewees (used to) have and of the colonial system as a whole.

Furthermore, the local context is of crucial importance as well (see e.g. Van De Mieroop 2009). In particular, this local context consists of the here and now of interviewees narrating and performing their stories in interaction with the interviewer, who of course also has an essential role in this process of meaning making given his dominant discursive position regarding topic selection, continuation and closure. So we view these interviews as 
interactional events (De Fina 2009: 237) in which the interaction with, and contributions of, the interviewer are regarded as a fully fledged part of the analyses (see e.g. Van De Mieroop and Clifton 2011) which deserves analytic attention and critical investigation (see e.g.

McIntosh 2009: 77). We thus focus strongly on the interactive nature of the identity negotiations between interviewer and interviewee and as such, we hope to partially overcome the criticism that identities in interview narratives are typically more stable and less fluid than the identity negotiations that occur in everyday interactions (see e.g. Bamberg 2006; Georgakopoulou 2006). By focusing specifically on the interaction with the interviewer, we highlight the co-constructed nature of these identities, and since interviews are typically sites in which people have extensive floor holding rights to discuss their life and "the purpose of narrating" (Johnstone 1996: 56) is precisely the creation of a self, such interview narratives still remain important sites for the study of identities. In turn, narrative is essential for the construction of identity because it "functions as the glue that enables human life to transcend the natural incoherence and discontinuity of the unruly everyday" (Bamberg, et al. 2007: 5), to such an extent that narrative and the construction of the self are even considered to be inseparable (Ochs and Capps 1996: 21). Furthermore, this reflexive nature of narratives and their typical goal to present the narrator within a coherent story in the best possible way, is especially interesting for our purpose. Since, as Linde observes, all personal narratives are shaped to illustrate that the speaker is a good person, and "therefore all such narratives must be changed or replaced as the speaker's understanding of what a good person is changes" (Linde 1993: 31). Hence, we may expect to find versions of life stories in our data that are adjusted to current day norms instead of being in line with the colonial ideology of the fifties and this will offer us a window into the changes in master narratives concerning the Belgian colonial past. Before we look into the way these master narratives are talked into being during these interviews about life in the Belgian Congo and how identities are constructed and 
negotiated against the backdrop of, and in interaction with, these dominant discourses, we first give a detailed description of our data.

\section{Data Description}

The interviews under study here were carried out and obtained through the efforts of an association $^{\mathrm{i}}$ that was founded in 2004 by a group of befriended former colonials with a twofold purpose in mind: on the one hand they aimed to collect the narratives of former colonials to preserve a crucial piece of Belgian cultural heritage. On the other hand they wished to aid scientific research regarding the Belgian Congo by securing the preservation of these narratives. The association pursues their main objectives by interviewing these former colonials and situating their activities in the field of oral history. Since 2004, the accounts of 266 former colonials were collected, and in cooperation with KADOC, the Documentation and Research Center for Religion, Culture and Society which is a part of the University of Leuven, these interviews were categorized and stored in their archives.

Because we take a closer look at the aspects of gender and ethnicity in this article, we limit ourselves to the in-depth study of four interviews with female former colonials ${ }^{\mathrm{ii}}$. The four interviews were videotaped and took place between 2005 and 2010, thus more than 45 years after the interviewees returned home from the Belgian Congo. All the interviewees were housewives who followed their husbands to Africa. They were all very positive about their experiences in the Belgian Congo and they all returned to Belgium against their will in 1959 or 1960 because of the Congolese independence. The interviews usually lasted for about half an hour, although one interview of this data subset was significantly longer, lasting up to almost one hour. Here is a more detailed description of the interviewees: 
1. Interviewee 1 is the wife of a car mechanic and the mother of two children who lived in the Belgian Congo for three years. She followed her husband to Africa six months after he left Belgium. She learnt French before travelling to Africa and a bit of Swahili while she lived there.

2. Interviewee 2 is the wife of a civil engineer who moved to the Belgian Congo in 1954 to work in a relatively small company of 30 engineers who studied major public works (such as bridges and roads). The interviewee followed her husband to the Belgian Congo after six months with their first baby who was only half a year old. She never learnt Swahili and spoke French with the African population.

3. Interviewee 3 lived in the Belgian Congo for eight years and she says she had always dreamed of moving to Africa since she was 10 years old. Her husband is a farmer who first worked for a small banana company and explored the southern part of the country to found new banana plantations, before changing jobs and starting to work in coffee plantations. They had four children, whom they sent home during the struggle for independence, while they hoped to stay in Congo. However, they had to flee the country soon after as well. This interviewee is the only one who looks back with slightly mixed feelings; on the one hand, she stresses the difficulty of living in the jungle for example, but on the other hand, she also emphasizes the wonderful time they had there.

4. Interviewee 4 was married to an agricultural engineer with whom she had two children. Her husband worked and travelled a lot in the jungle and she followed him on his travels. She says she learnt to speak Kikongo after a few months so that she could communicate with the native population. 
It is crucial to mention that these women were interviewed by the same interviewer who is a former colonial himself and who sometimes emphasizes his epistemic status as an expert regarding life and social norms in the Belgian Congo in his questions, sometimes explicitly asserting that he knows how the system worked or what family life typically looked like in those days. This makes these data particularly interesting for our analyses, since, rather than being typical research interviews with a relatively large distance between a neutral interviewer and the interviewees, these interviews are interactions between "former colleagues" so to speak, who sometimes even knew one another from the time they spent in the Belgian Congo. Of course, the interactional aspect and the interviewer's contributions are an important focus throughout our analyses.

\section{Analyses}

The stories studied here, focus specifically on the relation between the colonizers and the colonized, who are often - but not always - the indigenous household staff. This was typically a relation in which a power difference based on ethnicity was prescribed, but which, as many scholars have pointed out (McClintock 1995; Stoler 2001) could easily have turned out differently in practice, because either the black servants or the white rulers did not know their "place" (Stoler 2001: 843). Theoretically, this relation was typically "locked into a rigid hierarchy of difference deeply resistant to fair and equitable exchanges, whether economic, cultural or social" (Ashcroft, et al. 2006: 40-41) and because of this structurally embedded power difference in colonized countries, it is not surprising that this adherence to - or alternatively flouting of - the hegemonic order is a topic of discussion in the interviews.

Throughout the interviews, we see a strikingly consistent positioning of both the interviewees and the interviewer within the group of the powerful white colonials, as such 
also making gender irrelevant. These colonizers are constructed as "helpers," "caregivers" or "educators" of the powerless black people, who are usually not only presented as in need of help, care or education, but to whom often also negative characteristics such as limited intelligence, dishonesty and a lack of hygiene and compassion are attributed. We now present a number of excerpts from these interviews that illustrate this, before we go into a discussion of the implications of this construction of a typically "colonial" polarization of whites against blacks which seems quite anachronistic when situating these interviews in their current day contexts.

The first excerpt contains a story that is quite typical of the Belgian Congo, since this colonial regime intervened substantially in maternal and infant health care for the indigenous population and white women often played an important role in this endeavor (see e.g. Hunt 1997). In this narrative, the dichotomy of the colonized-in-need versus the caring colonizers is constructed, while attributing a slightly malicious trait to the former group and a naively idealistic trait to the latter group.

Excerpt 1 (interview 4) (a list of transcription conventions can be found at the end of the article)

150 IR U had dan ook (.) van dichtbij gezien

151 hoe de inlandse bevolking leefde (.) hun levensom[standigheden? [£Ja, dat $\uparrow$ wel£ .hh Ik h[eb ook='k had een cursus van EHBO gedaan in Antwerpen (.)

154 IR $\quad[($ da's $)$

155 IE en ik was eigenlijk zo gek idealist (.)

156 dat ik baby's ging verzorgen, euh mensen ging verzorgen. 
157 Bijzonder baby's .hh totdat ge na een maand of zes ontdekte

158 als ge verder trok en ge gaf ze wate: en boorwater

159 voor hun oogskes van die baby’s en @ £en ge waart nog niet $\uparrow$ weg

160 en ze waren het al aan het verkopen aan een ander£

161 IR@@

150 IR You had then also (.) seen from close by

151 how the native population lived (.) their living con[ditions?

152 IE

[£Yes, that $\uparrow$ yes£

153 .hh I h[ave also= I had done a course of first aid in Antwerp (.)

154 IR $\quad[$ (that's )

155 IE and I was actually so crazy idealist (.)

156 that I went to take care of babies, erm, went to take care of people.

$157 \quad$ Especially babies .hh until you discovered after about six months

158 if you travelled on and you gave them wate: and boracic water

159 for their little eyes of these babies and @ £ and you weren’t $\uparrow$ gone yet

160 and they were already selling it to another£

161 IR@ @

The interviewer asks a fairly neutral question regarding the interviewee's perception of the native population, thus projecting a role of privileged observer unto her. The interviewee affirms this role in line 152, but by using a smile voice and by the rising intonation, she already characterizes the upcoming answer as marked in a non-descriptive way. She then starts telling a story in which she first speaks from a personal perspective and presents herself as the active antagonist who took initiative to take care of the native people. By means of the 
use of specialized jargon in line 158 (“boracic water"), the interviewee constructs her identity as a healthcare professional (Kroskrity 2000: 112). However, she not only implicitly constructs herself as a professional caregiver and the native people as those in need, but she also explicitly qualifies herself as "so crazy idealist(ic)" (line 155), thus anticipating a potential characterization that the upcoming story entails. Interestingly, when shifting to the complicating action of the story, the interviewee shifts perspective to the vague you-form, which gives her story a more general applicability and neutralizes responsibility, because it potentially involves others, e.g. the interviewer or other listeners (Timor and Landau 1998). By generalizing agency for the action, she not only protects her own face from being threatened because of her naivety, but she also implicitly sets up a dichotomous world view, in which the black people are presented as a group and referred to in the $3^{\text {rd }}$ person plural pronominal form (see lines 158-160), while the colonials are referred to here by means of the vague you-form, thus potentially implying the listeners to the interview and implicitly projecting consensus upon this group.

Furthermore, as well as presenting two opposing groups, of which the former, i.e. the native population, is in need of help, this group is also presented as more interested in money than in healthcare. This point is made by telling an anecdote, namely the selling of boracic water meant to prevent ocular diseases in infants. This case not only makes the story more vivid, but it also presents an extreme case, since it focuses on failed healthcare for babies, who are of course the most helpless of all human creatures and who thus typically elicit protective reactions and lack thereof is perceived as incomprehensible. This helplessness is further emphasized by describing the babies' eyes by means of a diminutive form (“oogskes,” 'little eyes', line 159) and by preventing any ambiguity regarding the reference of the third person possessive pronominal form "hun" ('their', line 159), which, without the explicit attribution of the eyes to the babies in line 159, could have referred to the collective group of 
black people, voiced as "ze" ('them'), as well. Before narrating the point of the story, the interviewee laughs briefly, and while delivering the utterance, she uses a smile voice. The interviewer aligns with the treatment of this topic as a laughable, as is shown by his short laugh in the next line (cf Jefferson 1979: 83). So by means of this story, the interviewee constructs a dichotomy between the colonials and the indigenous people, not only regarding their role as either caregiver or in need of care, but also regarding what is considered as acceptable behavior from both perspectives.

Another important theme that often occurs in the interviews is the topic of education. Most interviewees discuss the need to educate their black staff, mainly to train them not to steal anything. An example of such a discussion can be seen in the following fragment, which is broken down in two excerpts ( $2 \mathrm{a}$ and $2 \mathrm{~b}$ ) because of its length.

\section{Excerpt 2a (interview 1)}

142 IE En 's morgens toen ik opstond (.) menne man die

143 was al weg naar de garage want die was mechanieker,

144 stond er daar in de deur ne zwarte (.) en die accueilleerde

145 mij met euh "Jambo, madame." $\underline{\mathrm{Da}}$ 'k niet wist wat da dat was.

146 En euh ik zei: “Ja, ja. Ja, ja (.) 't is goed.” Toen zei hij nog

147 ne keer: "Jambo, madame." en dan zei ik: [ "Kst (.) Kst (.) Kst (.)"

149 @[ [@

150IR_[@@

151 IE En dan heeft menne man ons voorgesteld, die is dan

152 gekomen, die heeft euh ons dan voorgesteld en ik heb altijd (.)

153 gedurende de jaren dat ik geweest ben, een prachtige 
154 verstandhouding gehad met mijne neger.

155 IR Met wie?

156 IE Met mijne neger, met mijn boy (.) met S.

157 Die noemde S. M. En 'k heb er een heel goede verstandhouding

158 mee gehad maar die heb ik wel (.) geleerd op mijn façon.

142 IE And in the morning when I got up (.) my husband

143 had already left for the garage because he was a mechanic,

144 there stood at the door there a black (.) and he welcomed

145 me with erm "Jambo ${ }^{\mathrm{iii}}$, madam." That I didn't know what that was.

146 And erm I said: "Yes, yes. Yes, yes (.) it's okay." Then he said another

147 time: "Jambo, madam." And then I said: ["Shoo (.) Shoo (.) Shoo (.)"

[(("send away" hand gestures $))$

14910[@@

150 IR_[@@

$151 \mathrm{IE}$ And then my husband introduced us, he came then,

152 he introduced erm us then and I have always (.)

153 during the years that I have been, had a wonderful

$154 \quad$ understanding with my negro.

155 IR With whom?

156 IE With my negro, with my boy (.) with $\mathrm{S}$.

157 He was called S. M. And I had a very good understanding

158 with him but I did (.) teach him in my way. 
In this fragment, the interviewee talks about her first morning in the Belgian Congo when she encountered her black employee. She first stipulates where her husband was in the orientation phase of the story, before moving into the actual story which consists of a short dialogue between the black employee and the interviewee. On the one hand, the former is constructed as well mannered, as not only the polite forms of address in the direct quotes (lines 145 and 147), but also the positive introductory "verbum dicendi" "acceuilleren" ('to welcome $^{\text {iv }}$ ), indicates. On the other hand, the interviewee presents herself here as unknowing (line 145) and oriented to closing the interaction as soon as possible. She first attempts this by responding with affirmative particles and the topic closing "it's okay" (line 146), but since this attempt is unsuccessful, she moves to paralinguistic means, namely by shooing him away, underlined by repeated hand gestures clearly indicating him to leave. These shooing noises are pronounced quite slowly with intermittent pauses, thus explicitly mimicking how she uttered these sounds. By means of this direct quote, she immediately constructs a hierarchical difference between herself and the black visitor, since she not only presents herself as having the power to send him away, but she also does so in a very face threatening way since the shooing sounds and hand gestures implicitly project an animal categorization upon the other interlocutor. Since the interviewee then immediately starts laughing, the face threatening nature of this utterance is quickly mitigated and this is aligned with by the interviewer who reciprocates this laughter.

The unsuccessful first encounter between the interviewee and the black employee is then repaired by means of the mediation of the interviewee's husband. The interviewee then evaluates her relationship with this employee in very positive terms, as the use of the semantically extreme adjective "prachtig” ('wonderful', line 153) (cf Edwards 2000) illustrates and she also labels her employee as "mijne neger" ('my negro', line 154). This label is quite marked, not only because of the use of the derogative term "neger," but also 
because the collocation with the first person possessive pronoun objectifies the person to a possession. This markedness also surfaces from an emic perspective, since the interviewer utters an understanding check in the subsequent line, after which the interviewee initially repeats this label, but then reformulates it to "mijn boy" ('my boy', line 156), thus substituting the derogative term "neger" with the job entitlement "boy" that was typically used for male servants in the Belgian Congo. After a pause, she again reformulates this second label to the servant's first name, which is then again clarified by a full sentence with both the servant's first and second name. After these reformulations and clarifications, the initial positive evaluation is repeated, but this time a reason for this evaluation is added, namely that the interviewee personally educated him. This reason is introduced by the contrastive conjunction "maar" ('but') and also the emphatic affirmative marker "wel” (translated as 'did (teach)', line 158) implies a contrast. This contrast points at an implied meaning, namely that the interviewee would not have had such a good understanding with her black servant if she had not taught him herself. As such, this sentence implicitly contributes to the construction of colonizers as the bringers of civilization and the need for Western education as a crucial condition for a successful relationship between blacks and whites.

This education is described in detail in the following excerpt, which immediately follows the previous one.

\section{Excerpt $2 b$ (interview 1)}

159 IE Den eersten dag had ik een grote kast met al mijn ( ) d'erin.

160 En toen riep ik hem en toen zei ik: "S." (("come-over-here” finger gesture))

161 Da wist 'k wat da was. (Nee nee) En hij zei mij: "Kuja.” [Dan schreef

$[\mathrm{Mmm}$.

163 IE ik op: “Komen (.) viens (.) kuja." [((hand gesture down and to the eye)) 
165 IE Angalia ((mimics writing)) regarder, hé. En ik telde alles (.)

166 [en als alles geteld was ] zei 'k: ["Goed, goed, oké, nzuri, ça va..”]

$167 \quad[(($ counting finger gestures $))] \quad[(($ emphasizing hand gesture $))]$

168 Hij verstond 't en ik [gaf hem de sleutel. ]

$169 \quad[(($ giving hand gesture $))]$

170 Ik zei: “Alles die weg is, gade betalen.” (.)

171 D'er is nooit niks weggeweest. Nooit niks.

159 IE The first day I had a big cupboard with all my ( ) in it.

160 And then I called him and then I said: "S." (( "come-over-here" finger

gesture))

161 I knew what that was. (No $\underline{\text { no }}$ ) And he said to me: "Kuja." [Then I

162 IR

$[\mathrm{Mmm}$.

163 IE wrote down: “Come (.) viens (.) kuja." [((hand gesture down and to the eye))

164 IR

$[\mathrm{Hmm}$.

165 IE Angalia ((mimics writing)) regarder, hey. And I counted everything (.)

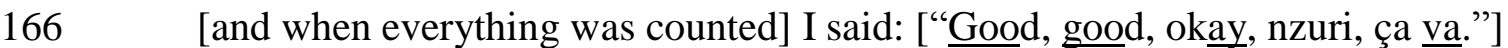

$167 \quad[(($ counting finger gestures $)) \quad] \quad[(($ emphasizing hand gesture $)) \quad]$

168 He understood and I [gave him the key. ]

$169 \quad[(($ giving hand gesture $))]$

170 I said: "Everything that is gone, you are going to pay." (.)

$171 \quad$ Nothing was never gone. Nothing never. 
In this fragment, the interviewee performs an interaction between herself and her black employee, which is in sharp contrast with the description of the initial encounter (excerpt 2a) in which the husband had to mediate between the interlocutors. In this case however, the focus shifts to the - typically feminine - realm of the household, which is an important space for the colonial women to interact with the indigenous people, who had a hierarchically lower position. This hierarchical difference is clearly enacted here, because the passive woman of the previous fragment seems transformed into an intelligent woman who is in control of the situation and superior to the black employee. This is shown by a number of elements: first of all, the interviewee takes initiative right away, as the temporal indication "the first day" indicates, secondly, she presents herself as not afraid to interact with, and, in case of disobedience, to punish (line 170), her black employee, thirdly, she illustrates how she proactively enhanced her linguistic skills by writing down words in Swahili and their translations and the social value of this linguistic interest (Anderson 2008: 112) demonstrates her willingness to communicate with the native population, fourthly, she demonstrates her didactic talent by explaining her intentions by means of explicitly mimicked gestures, which are really performed throughout this fragment, giving it an almost "parentese" quality (cf Kiesling 2001a: 265), thus illustrating how she succeeded in transcending linguistic inhibitions and finally, it emphasizes her skill to be in charge of things and people, since her closing evaluation demonstrates the effectiveness of her approach and this is further emphasized by a repeated, superfluously double, negation ("nooit niks," 'nothing never', line 171). But most importantly, it shows the interviewee's orientation to the necessity of teaching the "boy" not to steal, thus projecting an identity of "thief-by-nature" upon the black employee, who can only be trained not to steal. This implicature surfaces especially in the direct reported speech in line 170, in which the interviewee does not use a conditional phrase ("if something is gone..."), but instead, she factually states that missing items have to paid 
for, thus assuming that thefts will occur, and the absence of these thefts is attributed to the interviewee's managerial skills rather than an initial misjudgment of the employee.

Most interviewees tell specific stories about attempts to explain to their staff how to do odd chores in the household, as in the following excerpt.

\section{Excerpt 3 (interview 3)}

377 IE En dus dan=euh duikelde mijn man een manneke op uit de brousse he.

$378 \quad$ Eentje van zijn werkvolk (.) die in de plantatie werkte

379 en dat hij een een degelijk manneke vond, K, dertien jaar,

$380 \quad$ een heel vrolijk bazeke, en ik leerde hem alles

$381 \quad$ want hij kende niks niks, niks, niks.

$382 \quad$ Ik leerde hem alles en hij was zo ijverig

383 dat hij de vod al begon uit te kloppen

384 een meter voor dat hem bij het [raam was.

((IE mimics the movements with hand gestures $))$

377 IE And so then=erm my husband found a little guy from the wilderness hey.

378 One of his workmen (.) who worked in the plantation

379 and whom he thought to be a a reliable little lad, K, thirteen years,

380 a very cheerful little fellow, and I taught him everything

381 because he didn't know anything anything, anything, anything.

382 I taught him everything and he was so diligent

383 that he already started beating out the duster

384 a meter before he was at the [window. 
In this fragment, the interviewee describes how her husband found a new "boy" to help her in the household. In the initial lines, she describes that this "boy" was selected by her husband out of his workforce because of his reliability (line 379) and cheerfulness (line 380). These positive characteristics are corroborated by the interviewee, who underlines his diligence (line 382) by telling a story in which the "boy" beat out the duster before reaching the window, thus covering the house back in dust. This story is quite emphatically performed by the interviewee and it evokes laughter by the interviewer. Next to illustrating the black boy's diligence, it of course also underlines his lack of intelligence since his actions demonstrate his limited insight in the purpose of the chore at hand. This lack of insight or knowledge is also explicitly asserted by the interviewee in lines 380-382, in which an accumulation and repetition of the Extreme Case Formulations "everything" and "anything” (Pomerantz 1986) emphasizes the totality of his absence of knowledge. This of course sharply contrasts with the initial description of the selection of this candidate as one of the most reliable workers of the interviewee's husband and as such, it is implicitly established that blacks are either unreliable, lazy or stupid and that an absence of all these negative qualities cannot be expected in one black man.

In other parts of the interviews, there are many stories illustrating the interviewees' efforts to educate the native people on a more cognitive level. The following excerpt contains a story in which an interviewee bought two chickens from two black women (who are labeled “negerinnekes," 'little negresses', line 515) but she could not give the exact money to each woman. So the interviewee gave 50 francs to the first woman and 10 to the second, telling the first to give the second another 20 francs when she had change so that they both received 30 
francs. The excerpt starts with the end of the interviewee's explanation to the women, which is delivered in the form of direct reported speech in line 519.

\section{Excerpt 4 (interview 1)}

519 IE ["Nu moete gij twintig frank ] aan [haar geven."

$520 \quad[(($ hand gesture to one side $))] \quad[(($ hand gesture to the other side $))$

$521>$ Da kunde nie [begrijpen. <

522 IR

$[\mathrm{Hmm}$.

523 IE Dat is onmogelijk. [Ik heb dat uiteengelegd en nog ne keer

524 IR $\quad[\mathrm{Hmm}$.

525 IE uiteengelegd [.hh en toen dacht ik: <"Kijk, ik ga nu ne keer iets goeds doen.

$526 \mathrm{IR} \quad[\mathrm{Hmm}$.

527 IE Ik ga die kinderen ne keer een begrip inbrengen."> ((shakes head $))$

528 Jongen, dat [is (.) onmogelijk.

$529 \mathrm{IR} \quad\left[\mathrm{Hmm} \cdot{ }^{\circ} \mathrm{Ja}^{\circ}\right.$

$530 \mathrm{IE} \quad$ En dan heb ik met dat geld naar beneden geweest, naar ' $\mathrm{t}$

531 kantientje daar dat er was, de barak waar dat de zwarten iets gingen

532 gaan [kopen en heb ik dat gewisseld en dan heb ik ze elk dertig frank gegeven.

533 IR $\quad[\mathrm{Hmm}$.

534 IR Ja,((first name)), gij hebt daar wel een euh eeuwen euh Europese

535 euh opvoeding, mathematische opvoeding willen inprenten

$536 \quad$ [euh dus op enkele minuten.]

537 IE [En dat gaat niet he. ]

538 Zelfs mijnen $\downarrow \underline{\text { boy }}$ (.) euh ne man met twee kinderen. 
519 IE ["Now you have to give twenty francs] to [her."

$520 \quad[(($ hand gesture to one side $)) \quad] \quad[(($ hand gesture to the other side $))$

$521>$ You cannot [understand that. <

522 IR

$[\mathrm{Hmm}$.

523 IE That is impossible. [I have explicated that and explicated another

524 IR

$[\mathrm{Hmm}$.

525 IE time. [.hh and then I thought: <"Look, I will do something good for once.

526 IR $\quad[\mathrm{Hmm}$.

527 IE I will bring an insight into these children for once.”> ((shakes head $))$

528 Boy, that [is (.) impossible.

$529 \mathrm{IR} \quad\left[\mathrm{Hmm} .{ }^{\circ} \mathrm{Yes}^{\circ}\right.$

$530 \mathrm{IE} \quad$ And then I went downstairs with that money, to the

$531 \quad$ little canteen there that was there, the shed where the blacks went

532 to [buy something and I changed that and then I gave them each thirty francs.

533 IR $\quad[\mathrm{Hmm}$.

534 IR Yes, ((first name)), you did want to drum a erm centuries of erm European

535 erm education, mathematical education into there

$536 \quad$ [erm so in a few minutes. ]

537 IE [And that does not work hey.]

$538 \quad$ Even my $\downarrow$ boy (.) erm a man with two children.

As the intonational stress and accompanying hand gestures in lines 519-520 indicate, the explanation about the division of the money is delivered again in an emphatic and didactic way, much in the same way as in excerpts $2 b$ and 3 . After this final part of the explanation, the interviewee switches to a metalevel, in which she first uses the generic second person 
pronominal clitic dialect form "-de" (translated as 'you', line 521), thus addressing the interviewer and all the other potential listeners. She generalizes further in the following line by making a factual statement with intonational stress on the prefix of negation "on-" ('im-', line 523). She then shifts back to the story frame and stresses her efforts by mimicking the extensiveness of her explanation by the repeated use of the verb "to explicate." Then, by explicitly voicing her intentions, she relates these explanations to a project "to do good" (line 525) and "to bring insight" (line 527), thus clearly framing it within the western colonial model of the benign education of the natives, who are labeled here as "children" (line 527). This label evokes the "standardized relational pair" (Sacks 1972) of parent-child, which entails a number of rights and obligations for each role, implies a hierarchical difference between each pair part and evokes the master narrative of white colonials bringing civilization to the indigenous, childlike people. After voicing these intentions, the interviewee repeats the factual negative evaluation of the educational project that was already voiced in line 523 . The interviewee then continues with the storyline, presenting the resolution (Labov and Waletzky 1966) in lines 530-532 in which she constructs herself as the active agent who resolves the problem.

Interestingly, in the next turn, the interviewer shifts the topic back to the interviewee's failed educational project and on the one hand, corroborates the interviewee's negative evaluation by putting the story in a wider frame, in which the anecdote is now framed within mathematical education with a long standing European tradition, as such also polarizing the two continents, Europe versus Africa. However, the interviewer also projects a certain naivety and lack of didactic insight onto the interviewee because of the extreme temporal contrast between the "centuries" of European education versus the "few minutes" of education provided by the interviewee. In overlap with the final part of the interviewer's turn, the interviewee aligns with this evaluation and then moves into the orientation phase of another 
story illustrating the same point. The introductory adverb "zelfs" ('even', line 538), related to the protagonist of the story (i.e. the interviewee's male servant), frames this role as ineducable black person for the "boy" as contrary to expectations, which, after a brief pause, is then linked to his gender and his status as a parent (line 538).

So in this fragment, the interviewee and the interviewer implicitly co-construct a stratified society in which hierarchical relations are talked into being on the basis of ethnicity, and, to a minimal extent, also gender. First of all, black people are constructed as children in need of education, and given the fact that this is presented as unsurprising for black women in opposition to black men, the former have the lowest position. Secondly, white people are constructed as the parents/educators of the black, and it may even by argued on the basis of the contribution of the interviewer in lines 534-536 that women are constructed as holding a lower position than the men. As such, the traditional view of the evolutionary scale of human types based on race and gender is talked into being, while at the same time the lack of success of educating the indigenous people is asserted and related to the general absence of cognitive qualities in black people, much in the same way as it was reported to the Belgian Ministry of Colonies as described by Fabian (see Fabian 1986: 50).

While studying these interviews, we have been looking extensively for counterexamples of this typical construction of the colonial polarization of whites versus blacks. However, only a few stories emerged as possible counters of these colonial viewpoints, and even in these cases, the underlying premises are still convincingly colonial. An example can be seen in the following excerpt:

\section{Excerpt 5 (Interview 2)}

135 IE Ik had een boy voor de keuken en enen voor de hof, 136 gelijk iedereen dat had. En euhm soms inviteerde ik ze zelfs 
137 op de verjaardag van mijn kinderen, inviteerde ik ook (.) hun kinderen. (.)

138 Ik werd daar soms een keer voor gekritiseerd, maar dat kon mij niet schelen.

139 IR Uw kinderen (.) of uw kindjes toen, dat was: hadden waarschijnlijk

140 een zeer sterke band met de kinderen van uw personeel he?

$141 \mathrm{IE} \quad \mathrm{Ja} \uparrow \mathrm{ja}$. Omdat er waren (.) dat waren boys

142 die eigenlijk eu:::h in de brousse opgevoed waren door paters he.

143 En die (.) allez (.) we hadden (.) die hadden een geweldig goede band met ons.

144 En, we waren er ook goe- ja wat dat er over bleef van het eten

145 was voor hun. Het is daarmee.

135 IE I had a boy for the kitchen and one for the garden,

136 like everyone had that. And erm sometimes I even invited them

137 to the birthday of my children, I also invited (.) their children. (.)

138 I was criticized for that from time to time, but I didn't care.

139 IR Your children (.) or your little children then, that was: had probably

140 a very strong bond with the children of your personnel hey?

$141 \mathrm{IE} \quad$ Yes $\uparrow$ yes. Because there were (.) that were boys

142 who actually e:::rm were raised in the wilderness by priests hey.

143 And who (.) well (.) we had (.) they had an incredibly good bond with us.

$144 \quad$ And, we were also good to- yes what was left of the food

145 was for them. That is why.

In the initial lines of the fragment, the interviewee narrates the orientation phase of the story, in which she qualifies her household as a typical one in colonial Congo. This is underlined by the use of the Extreme Case Formulation (Pomerantz 1986) "everyone" (line 
136). Then she continues to narrate an exceptional situation, which is framed as such by the combination of the hedge "sometimes" and the booster "even" (line 136). The exceptionality of the situation revolves around the fact that the interviewee invited the black staff's children to the birthday parties of her own children. She sets up an opposition between herself and her staff, as the marked prosody of the opposing possessive pronouns in line 137 ("my" versus "their") indicate. This topic is then closed in the subsequent line, in which the interviewee formulates a coda to the story. In this coda, the interviewee asserts that she is criticized because of this, but that it did not affect her. As such, she not only presents herself as a strong woman with a strong opinion, but also as having exceptional views on racial segregation which typically receive criticism. Through the use of the passive voice, the authors of the criticism are omitted, and the strong hedging ("from time to time," line 138) of the statement further downplays the polarization between the interviewee and other colonials.

The interviewer then pursues this topic further by probing for the bonds between the interviewee's children and the children of her personnel. Interestingly, the question is formulated in quite a leading way and it almost projects a positive answer upon the interviewees, which seems to be contrary to the colonial idea of racial segregation. However, because of the interviewer's initial reformulation, he emphasizes the young age of the children ("Your children (.) or your little children," line 139) and as such, he does not really contradict the colonial idea of natural hierarchies. This is because from this point of view, all the blacks are like children and thus bonds between black and white children are not considered problematic, but rather something that the white children will outgrow once they become adults, which the black children are deemed incapable of.

The interviewee corroborates the interviewer's suggestive question, but she then goes on to account for this relation between her children and those of the black staff by asserting the relatively cultivated nature of her "boys" (line 141). Crucially, this is explicated because of 
her staff's upbringing by missionary priests in the wilderness (line 142), who typically first established the African "as degenerate other; then they would take hold of him in a transforming grasp that would harness his brute potential, making him into a lowlier, artless version of themselves" (Comaroff and Comaroff 1991: 109), and who aimed for a transformation or even a "total reconstruction" (Comaroff 1997: 181, italics in the original). Especially because this argument of the blacks' upbringing is framed as an account of why the staff's children could socialize with white children, it supports the idea of the blacks who are degenerate by nature but who can partially outgrow this through the careful nurture of the missionaries, thus framing the entire colonization system as benevolent and beneficial for the African population. In the following line, the interviewee positively evaluates the bonds between themselves and their staff in more general terms, but, as the initial reformulations and pauses indicate, she also struggles with the agency of this relation, which she eventually puts in the hands of the staff ("they had," line 143). Then, she expands on this relation from their own perspective (“we," line 144), and, importantly, the interviewee shifts back to hierarchical terms and describes herself and her kin as the benevolent colonizers who grant the leftovers to their staff. The short closing sentence ("That is why," line 145) retrospectively frames the previous lines as an account for the existence of this close relation between the interviewee and her staff, thus firmly nesting her words within the governing ideology of the colonial period in which hierarchical differences between blacks and whites were considered natural.

\section{Discussion and Conclusions}

In the analyses, we discussed the relations between black people and the female interviewees mainly in the household realm. The interviewees typically construct active positions for themselves and take up the roles of caregivers, household managers and 
educators who are socially involved, smart and altruistic. As such, they present themselves as benevolent colonizers who orient themselves to the construction of "a good self, and a self that is perceived as good by others" (Linde 1993: 122) when looking at this matter from a colonial point of view. Since their stories reflect the master narrative of colonization as the bringing of civilization to the natives, who are constructed as having questionable moral values and limited intelligence, they legitimize the colonial system through their stories. Furthermore, the interviewees construct a hierarchical and moral difference between themselves and the indigenous people and for example by explicitly referring to the standardized relational pair of parent-child as in excerpt 4 or by enacting "parentese" as in excerpt $2 b$, they implicitly draw on the concept of natural hierarchies in which black people are infantilized (Comaroff and Comaroff 1991: 117) and occupy a low position in the evolutionary scale of human types. Even when this difference at first sight seems to be minimized, as in excerpt 5, the underlying ideology still remains strongly nested within the colonial viewpoints of blacks as savages who can make a certain amount of progress when they are educated by benevolent colonizers.

As has been shown extensively before, the interaction between the interviewer and the interviewees always has a significant influence on the way identities are performed within interview narratives (De Fina 2011; Kiesling 2001b: 113; Trechter and Bucholtz 2001: 10-11) and so we now focus on the influence the interviewer had on the construction of meaning in these stories. First of all, we observe that the interviewer hardly ever challenges the interviewees, rather, he contributes to their stories mainly by voicing continuers, aligning through laughter and co-constructing the African population as savage and childlike. Secondly, it is also crucial to note that potentially face threatening topics such as aggression towards, or physical punishments of, the native people are noticeably absent in these interviews. Thirdly, the gender difference between the interviewer and the interviewees is 
only rarely made relevant in these stories (with the exception of the implicit setup of a hierarchical difference based on gender and ethnicity in excerpt 4). However, it comes to the fore quite explicitly elsewhere in the interviews when other topics are discussed (especially concerning the relation between the interviewees and their husbands). So this difference is downplayed here and as such, the similarities between the interlocutors are highlighted, which are, in this case, based on ethnic grounds. So the supportive position of the interviewer contributes to the construction of an ingroup between the interviewer and the interviewees, which can be defined as that of the white colonizers as opposed to the black "other."

So interestingly, the stories that are told about the relation between whites and blacks in the colonial household do not reflect the hybridity and variation that many scholars on colonization have pointed at (e.g. Stoler and Cooper 1997: 9), but rather they talk into being Manichaean dichotomies between the colonizers and the colonized which are firmly situated within the governing colonial ideology of the fifties in which power was legitimized through the infantilization of black people who benefited from the care of the whites who brought civilization to the wilderness. Thus the stories seem frozen in time, which is a remarkable finding given the fact that the interlocutors have had a couple of decades to reflect on what happened in the Belgian Congo, thus creating many occasions for self-regard and editing of their stories (Linde 1993: 105) along the lines of postcolonial ways of thinking. One could argue that this is due to the fact that the interviewer was also a former colonial whom some of the interviewees knew personally from their time in the Belgian Congo. Throughout the interviews, there are points in which the interviewer demonstrates his knowledge of the colonial customs in the fifties and this shared background may have encouraged the interlocutors to jump back into the past and almost "forget" modern views on colonization. However, although there is probably some degree of truth in this explanation, we think that there is another reason for this, namely that this construction of the dichotomy between blacks 
and whites is related to the way colonial history is dealt with in Belgium. In a recent article, Goddeeris (2011) claims that the debate on its colonial past is fairly muted in Belgium and especially in Flanders, mainly because of the absence of post-colonial immigrants who typically have a clear voice in such debates countering that of the former colonizers. Rather, Africans remains an object in the debate, rather than receiving an active role (Ceuppens 2007). Emblematic for this is the fact that in Belgium, King Leopold II - who was especially known for his atrocities in Congo before it became a Belgian colony (Cooper and Stoler 1989: 618) - still has a number of statues with quotes framing colonization as an endeavor of civilization and these emblematic monuments are even unquestioningly restored when they are vandalized. This is in sharp contrast with the neighboring countries such as the Netherlands, where monuments are erected to honor the victims of colonization (Goddeeris 2011: 44-46). Even after the many celebrations in relation to Congo in the last few years ${ }^{\mathrm{v}}$ and the accompanying publication of many books and broadcasting of many documentaries on Congo (see e.g. Theerlynck 2012), Belgium has remained fairly introspective in its views on its colonial history and no real polemic regarding postcolonial issues ever emerged (Goddeeris 2011). Thus exposure of the general public to postcolonial thinking may remain relatively limited in Belgium in comparison with what happens in other former colonizing countries and it is exactly this situation which is reflected in these interview narratives. As such, they do not only offer a - highly subjective - window into the past, but also a window on the present, and especially on the absence of a broad public debate on Belgian colonial history which synthesizes voices both from the side of the former colonizers and the colonized (cf Goddeeris 2011: 47). 
Transcription conventions (based on and taken from Antaki 2002)

\begin{tabular}{|c|c|}
\hline $\begin{array}{l}\text { Transcription symbols in examples taken } \\
\text { from the fragments }\end{array}$ & Explanation \\
\hline (.) & Brief pause \\
\hline$\uparrow$ yes, $\downarrow$ boy & Onset of noticeable pitch rise or fall \\
\hline $\begin{array}{lll}536 & \text { IR } & \text { [erm so in a few minutes. } \\
537 & \text { IE } & \text { [And that does not work hey. ] }\end{array}$ & $\begin{array}{l}\text { Square brackets '[' aligned across adjacent } \\
\text { lines denote the start of overlapping talk. } \\
\text { Other square brackets ']' show where the } \\
\text { overlap stops }\end{array}$ \\
\hline e:::rm & $\begin{array}{l}\text { Colons show that the speaker has stretched } \\
\text { the preceding sound }\end{array}$ \\
\hline hh & Audible inbreath \\
\hline (that's) & $\begin{array}{l}\text { Uncertain transcription due to audio- } \\
\text { problems }\end{array}$ \\
\hline then $=$ erm & $\begin{array}{l}\text { The equals sign shows an example of } \\
\text { latching, which means that there is no } \\
\text { discernible pause between a speaker's or two } \\
\text { speakers' turn(s) }\end{array}$ \\
\hline anything & Underlined sounds are louder \\
\hline${ }^{\circ}$ Yes. ${ }^{\circ}$ & Words between degree signs are quieter \\
\hline $\begin{array}{l}>\text { You cannot understand that. < } \\
<\text { "Look, I will do something good for once. I } \\
\text { will bring an insight into these children for } \\
\text { once."> }\end{array}$ & $\begin{array}{l}\text { Inwards arrows show faster speech; } \\
\text { outward slower }\end{array}$ \\
\hline
\end{tabular}




\begin{tabular}{|l|l|}
\hline$£$ Yes, that $\uparrow$ yes $£$ & $\begin{array}{l}\text { The words between £-signs are spoken in a } \\
\text { 'smile voice' which has a markedly higher } \\
\end{array}$ \\
& $\begin{array}{l}\text { pitch and an intonational contour comparable } \\
\text { to laughing during speaking but without any } \\
\text { laughter tokens }\end{array}$ \\
\hline$(($ giving hand gesture $))$ & Representation of something hard, or \\
& impossible, to write phonetically \\
\hline$@$ & Laughter token \\
\hline
\end{tabular}

\section{References}

Anderson, Kate T.

2008 Justifying Race Talk: Indexicality and the Social Construction of Race and Linguistic Value. Journal of Linguistic Anthropology 18(1):108-129.

Antaki, Charles

2002 An introductory tutorial in conversation analysis. Available at: http://wwwstaff.lboro.ac.uk/ssca1/notation.htm, accessed May 6, 2013.

Ashcroft, Bill, Gareth Griffiths, and Helen Tiffin

2006 Post-colonial studies: the key concepts. Oxondon: Routledge.

Bamberg, Michael

2006 Stories: Big or small; Why do we care? Narrative Inquiry 16(1):139-147.

Bamberg, Michael, Anna De Fina, and Deborah Schiffrin

2007 Introduction to the volume. In Selves and Identities in Narrative and Discourse.

M. Bamberg, A. De Fina, and D. Schiffrin, eds. Pp. 1-8. John Benjamins: Amsterdam.

Bruner, Jerome S. 
1991 Self-making and world-making. Journal of Aesthetic Education 25(1): 67-78.

Ceuppens, Bambi

2007 “U bent mij vergeten, I presume?" [“You have forgotten me, I presume?”].

Mo*, online available at: http://www.mo.be/opinie/u-bent-mij-vergeten-i-presume, accessed May 6, 2013.

Comaroff, Jean, and John L. Comaroff

1991 Of revelation and revolution: Christianity, Colonialism, and Consciousness in South Africa. Volume one. Chicago / London: The University of Chicago Press.

Comaroff, John L.

1997 Images of Empire, Contests of Conscience: Models of Colonial Domination in South Africa. In Tensions of Empire: Colonial Cultures in a Bourgeois World. F.

Cooper and A.L. Stoler, eds. Pp. 163-197. Berkeley: University of California Press.

Comaroff, John L., and Jean Comaroff

2009 Ethnicity, inc. Chicago: University of Chicago Press.

Cooper, Frederick, and Ann L. Stoler

1989 Introduction: Tensions of Empire: Colonial Control and Visions of Rule.

American Ethnologist 16(4):609-621.

De Fina, Anna

2009 Narratives in interview - The case of accounts; For an interactional approach to narrative genres. Narrative Inquiry 19 (2):233-258.

De Fina, Anna

2011 Researcher and informant roles in narrative interactions: Constructions of belonging and foreign-ness. Language in Society 40:27-38.

De Fina, Anna, Deborah Schiffrin, and Michael Bamberg 
2006 Introduction. In Discourse and Identity, Studies in Interactional

Sociolinguistics 23. A. De Fina, D. Schiffrin and M. Bamberg, eds. Pp. 1-23.

Cambridge: Cambridge University Press.

Edwards, Derek

2000 Extreme Case Formulations: Softeners, Investment, and Doing Nonliteral.

Research on Language and Social Interaction 33(4):347-373.

Errington, Joseph

2001 Colonial Linguistics. Annual Review of Anthropology 30:19-39.

Errington, Joseph

2008 Linguistics in a Colonial World: A Story of Language, Meaning, and Power. Malden: Blackwell.

Fabian, Johannes

1986 Language and Colonial Power: The Appropriation of Swahili in the Former Belgian Congo 1880-1938. Cambridge: Cambridge University Press.

Georgakopoulou, Alexandra

2006 Thinking big with small stories in narrative and identity analysis. Narrative Inquiry 16(1):122-130.

Goddeeris, Idesbald

2011 Congo in onze navel: De omgang met het koloniale verleden in België en zijn buurlanden [Congo in our navel: The way of dealing with the colonial past in Belgium and its neighboring countries]. Ons Erfdeel 54(1):40-49.

Hanks, William F.

2010 Converting Words: Maya in the Age of the Cross. Berkeley: University of California Press.

Hermans, Jef 
2010 De leef- en denkwereld van een koloniaal en zijn gezin in Belgisch Kongo (1947-1960) [The life and mental world of a colonial and his family in the Belgian Congo (1947-1960)]. Unpublished, available at http://www.scriptieprijs.be/uploads/documentenbank/295ff1f07182744bb554c242eb3 8109a.pdf , accessed September 26, 2011.

Hesselink, Hans

2008 Woordenboek Nederlands -Swahili-Nederlands [Dictionary Dutch-SwahiliDutch]. Tubbergen: Hesselink.

Hunt, Nancy Rose

1997 “Le bébé en brousse:” European Women, African Birth Spacing, and Colonial Intervention in Breast Feeding in the Belgian Congo. In Tensions of Empire: Colonial Cultures in a Bourgeois World. F. Cooper and A.L. Stoler, eds. Pp. 287-321. Berkeley: University of California Press.

Jefferson, Gail

1979 A technique for inviting laughter and its subsequent acceptance/declination. In Everyday Language: Studies in Ethnomethodology. G. Psathas, ed. New York: Irvington.

Johnstone, Barbara

1996 The linguistic individual. Oxford University Press: New York/Oxford. Kiesling, Scott F.

2001a “Now I Gotta Watch What I Say:” Shifting Constructions of Masculinity in Discourse. Journal of Linguistic Anthropology 11(2):250-273.

Kiesling, Scott F.

2001b Stances of Whiteness and Hegemony in Fraternity Men's Discourse. Journal of Linguistic Anthropology 11(1):101-115. 
Kroskrity, Paul V.

2000 Identity. Journal of Linguistic Anthropology 9 (1-2):111-114.

Labov, Willam, and Joshua Waletzky

1966 Narrative Analysis: oral versions of personal experience. In Essays on the Verbal and Visual Arts. J. Helm, ed. Pp. 12-44. Universiy of Washington Press:

Seattle.

Linde, Charlotte

1993 Life Stories, the creation of coherence. Oxford University Press: New York / Oxford.

McClintock, Anne

1995 Imperial Leather: Race, gender and sexuality in the colonial contest. London:

Routledge.

McIntosh, Janet

2009 Stance and Distance: Social Boundaries, Self-Lamination, and Metalinguistic Anxiety in White Kenyan Narratives about the African Occult. In Stance:

Sociolinguistic Perspectives. A. Jaffe, ed. Pp. 72-91. Oxford: Oxford University Press.

Ochs, Elinor, and Lisa Capps

1996 Narrating the self. Annual Review of Anthropology 25:19-43.

Pomerantz, Anita

1986 Extreme Case formulations: A way of legitimizing claims. Human Studies 9(2):219-229.

Sacks, Harvey

1972 An initial investigation of the usability of conversational data for doing sociology. In Studies in social interaction. D. Sudnow, ed. Pp. 31-74. Free Press: New York. 


\section{Stienissen, Geert}

2009 De vrouw in Congo (deel 1): huishoudsters, geen politici [The woman in Congo (part 1): housekeepers, no politicians]. Available at: http://www.congoforum.be/ndl/analysedetail.asp?id=16499\&analyse=selected, accessed September 26, 2011.

Stoler, Ann L.

1997 Sexual Affronts and Racial Frontiers: European Identities and the Cultural Politics of Exclusion in Colonial Southeast Asia. In Tensions of Empire: Colonial Cultures in a Bourgeois World. F. Cooper and A.L. Stoler, eds. Pp. 198-237. Berkeley: University of California Press.

Stoler, Ann L.

2001 Tense and Tender Ties: The Politics of Comparison in North American History and (Post) Colonial Studies. The Journal of American History 88(3):829-865.

Stoler, Ann L., and Frederick Cooper

1997 Between Metropole and Colony: Rethinking a Research Agenda. In Tensions of Empire: Colonial Cultures in a Bourgeois World. F. Cooper and A.L. Stoler, eds. Pp. 1-56. Berkeley: University of California Press.

Timor, Uri, and Rachel Landau

1998 Discourse characteristics in the sociolect of repentant criminals. Discourse \& Society 9(3):363-386.

Theerlynck, Sarah

2012 Voor onze missies, dank u [For our missions, thank you]. De Morgen 24 September 2012: 6.

Trechter, Sara, and Mary Bucholtz 
2001 White Noise: Bringing Language into Whiteness Studies. Journal of Linguistic Anthropology 11(1):3-21.

Van De Mieroop, Dorien

2009 A good story or a good identity? The reportability of stories interfering with the construction of a morally acceptable identity. Narrative Inquiry 19(1):69-90.

Van De Mieroop, Dorien, et al.

2007 Implicit and explicit identity constructions in the life story of one of Hitler's elite soldiers. Discourse Studies 9(3):385-405.

Van De Mieroop, Dorien, and Jonathan Clifton

2011 Standardized relational pairs in interviews with former slaves: construction, negotiation and alignment. Narrative Inquiry 21(1):44-67.

Van Dijk, Teun A.

2009 Society and Discourse, How Social Contexts Influence Text and Talk.

Cambridge: Cambridge University Press.

Verlinden, Peter

2002 Weg uit Congo. Het drama van de kolonialen [Away from Congo. The drama of the colonials]. Leuven: Davidsfonds.

Wortham, Stanton, et al.

2011 Racialization in Payday Mugging Narratives. Journal of Linguistic Anthropology 21(1):56-75.

\section{Notes}


${ }^{\mathrm{i}}$ For reasons of anonymity, we agreed not to disclose the name of the association nor to provide too many details regarding the data collection.

${ }^{\text {ii }}$ Because no full access to the entire corpus was granted to us, we explained our goals and interests to the corpus manager who selected these interviews for us.

iii Jambo is a greeting in Swahili meaning ‘Good day’ (Hesselink 2008).

iv This is a corrupted Dutch verb of French origin. Many such corrupted Dutch words occur in the interviews which can be related to the fact that French was often spoken in Congo.

v 2008: Centennial of the foundation of The Belgian Congo; 2009: the Centennial of the death of King Leopold II and 2010: the fiftieth anniversary of the Congolese independence 